\title{
Something Missing: Czech Society and Transcarpathia after 1989
}

\author{
Tomáš ZAHRADNÍČEK
}

\begin{abstract}
The article studies the "afterlife" of the former Subcarpathia, the present-day Transcarpathia, within the Czech society after 1989. The discourse about the region was framed by the understanding of the Czech society of their revolution of 1989 primarily in terms of political and cultural return to the inter-war Masarykian Republic. It maps the different ways the Czech society coped with this deficit in its restoration endeavours in the early 1990s. Within the Czech public discourse uncritical conception of selfless and successful civilising mission in the East still prevails, based on a belief that local population gratefully accepted and now nostalgically longs for such input. For some time after 1989, the theme became one of the key components of Czech debates concerning the past, its neighbours and own identity within the integrating Europe.
\end{abstract}

\section{Keywords}

Subcarpathia, Transcarpathia, cultural restoration, borders, Czechoslovakia

The study explores the "afterlife" of the former Subcarpathia", the present-day Transcarpathia, within the Czech society after 1989. The Czechs understood their revolution of 1989 primarily in terms of political and cultural return to the inter-war Masarykian Republic. A number of conditions required for such restoration were missing, most importantly the consent by the Slovaks. A portion of the territory was missing too: the easternmost part of Czechoslovakia - Subcarpathia - was annexed by the Soviet Union in 1945. This study maps the different ways the Czech society coped with this deficit in its restoration endeavours in the early 1990s. Within the Czech public discourse uncritical conception of selfless and successful civilising mission in the East still prevails, based on a belief that local population gratefully accepted and now nostalgically longs for such input. For some time after 1989, the theme became one of the key components of Czech debates concerning the past, its neighbours and own identity within the integrating Europe.

The discussion after 1989 was shaped to a large extent by an article, which appeared ten

1 The term Subcarpathia is used in the text to translate two Czech terms: Podkarpatsko and Podkarpatská Rus (Subcarpathian Russia). 
years previously in the exile magazine Svědectví (Testimony). It was written in New York by Ivo Ducháček, then recently retired lecturer in political science. He returns to the last months of the Second World War when he served in the London Czechoslovak Government in Exile as a Director of the Office of the Minister of Foreign Affairs. He published a commented collection of despatches, which he received in London on the break of 1944 and 1945 from an undercover broadcasting station in Subcarpathia. In the dispatches, the Czechoslovak officials in the rear of the Soviet Army described the thorough state-controlled organisation of "spontaneous expressions" of local populace who allegedly called for unification with the Soviet Ukraine. Consequently, at the end of January 1945 Stalin informed Beneš that he had to amend his earlier statement, in which he recognised Czechoslovakia within its pre-Munich borders. The Soviet-Czechoslovak Treaty de iure confirming the de facto annexation of Transcarpathia was signed in June 1945 and was smoothly ratified by the provisional Czechoslovak Parliament six months later. After his return from London exile, Ivo Ducháček, eyewitness to these events became an important member of the parliament. He commented the ratification of the Treaty, by saying: "The Chairman of the Peoples Party Jan Šrámek approved of the constitutional law on secession of Subcarpathia on quite specific grounds. He told the author: 'It is better for the constitutional law to be adopted now by the un-elected provisional parliament, than if it were to be done by the next, elected legislature. The whole thing is null and void, because the unelected, nominated National Assembly has no right to change the Constitution.' "2 Ducháček did not comment the opinion of the Deputy Prime Minister of the post-war government. Yet, it is possible that Ducháček, who spent his long career life on the threshold between journalism, diplomacy, academia and intelligence, was well aware of what he was doing when he wrote, what he did.

\section{Society of Friends of Subcarpathia}

After the fall of communism in Central and Eastern Europe the Czech press dwelled for months about the past, to a hitherto and since unheard of extent. Free public discourse in the Czech Lands had ended in 1938. Since then substantial developments occurred that required discussion. The weekly Reportér published an article entitled Subcarpathian Question Marks. It drew from extensive knowledge of the subject and concluded with a rhetoric statement suggesting that the annexation of Transcarpathia in 1945 was carried out illegally: "What are we going to do with this heritage of Stalinism?" 3 The attached list of references also contained Ducháček's text from Svědectví and other hard-to-obtain exile publications. The article was signed by a pen name Jan Skotarský. It was used by

2 DUCHÁČEK, Ivo: Jak Rudá armáda mapovala střední Evropu: Těšínsko a Podkarpatsko, in: Svědectví, 1981, 63, 541-581, quote on the page 575. The argument about invalidity of the annexation of Subcarpathia by the Soviet Union appeared repeatedly in the debates of part of the post-war political exile. The Government in Exile, the Council of Free Czechoslovakia, issued a special declaration about this issue. But it had no impact because of the general weakness of the Czech and Slovak exile institutions. Moreover, they failed to integrate the exile Subcarpathian associations, which since the late 1940s in Western Europe and especially Northern America operated independently. See RAŠKA, Francis D.: Fighting Communism from Afar: The Council of Free Czechoslovakia, Boulder 2008.

3 SKOTARSKÝ, Jan: Podkarpatské otazníky, in: Reportér, 1990, 5, 13, 18-22, quote from p. 22. 
the young Vladimír Kuštek who was then junior official of the Federal Ministry of Foreign Affairs. He was linked to the issue through personal ties. From then on, without official authorisation, he kept launching his own initiatives until his diplomatic appointment on behalf of Slovakia. ${ }^{4}$

The author of the second text was well known. The article Freedom is Indivisible published in the weekly Tvorba was written by Jaromír Hořec, an established cultural figure. Man with multifaceted interests was continuously present in public life as poet, editor, journalist, author of lyrics and historical studies since 1945. In his article he argues that the secession of the region to the Soviet Union is to be considered void: "In any future negotiations about the new identity of Central Europe, Subcarpathia needs to be considered part of Czechoslovakia, whose borders should return to the state of the period 1918-1937." He supported his argument by saying that Czechoslovakia had a moral duty towards its former citizens whom it had transferred to Soviet Ukraine. An argument emerged suggesting that Czechoslovakia should get involved in Transcarpathia in order to support the national movement of Ruthenians. According to Hořec, the people of Transcarpathia were Ruthenians who underwent Sovietisation and Ukrainisation after 1945. The Ruthenian national movement fared best in the inter-war Czechoslovakia, which was to be the case in the future as well. "The right to freedom does not belong only to the outspoken nations and those who can struggle for their freedom, but also to those who live within totalitarian dictatorship, were prosecuted and intimidated in the past to such an extent that they were practically silenced. The freedom of Central Europe belongs to all the nations who lived here for centuries and created cultural heritage of permanent value. It is not only for some nations. It is indivisible," wrote Hořec. ${ }^{5}$

The article came as a wakeup call. ${ }^{6}$ Preparation committee was promptly set up around Hořec and at the end of October 1990, the first general assembly of the new Society of Friends of Subcarpathia with over two hundred people met in the Prague-based cinema Kyjev. ${ }^{7}$ It adopted a founding declaration that referred to the interwar Czechoslovakia as an "island of freedom and democracy". In another part it refers to it as the country "dedicated to the thoughts of humanistic democracy", which became common home to three nations - the Czechs, Slovaks and Subcarpathian Ruthenians. According to the declaration, the people of Subcarpathia were still "loyal to the democratic legacy of the Czechoslovak Republic". The goal of the new Society was to "lend a friendly hand" and "assist them in returning to Europe." There was only a single specific demand addressed to Czechoslovak authorities: "We ask that the Ruthenian nationality should be officially

4 Interview with Vladimír Kuštek, Prague 1 June 2011, At the time of revising this text (2017), V. Kuštek is regular contributor of historical articles to the journal Podkarpatská Rus published in Prague.

5 HOŘEC, Jaromír: Nedělitelná svoboda, in: Tvorba, 1990, 15, 11. Also reprinted in: HOŘEC, Jaromír: Nedělitelná svoboda. Podkarpatská Rus, Prague 1992, 5-10.

6 Cf. for instance with the statement by a journalist Agáta Pilátová, later one of the most active promoters of Transcarpathia in the Czech press and organisers of the new Society: "With a touch of envy I say that that I ought to write such an article. For a long time I feel it as my moral duty. And there are many more people like me who feel personally involved in this." Tvorba, 1990, 20, 18.

7 Zápis z 1. valné hromady Společnosti přátel Podkarpatské Rusi (Records of the First General Assembly of the Society of Friends of Subcarpathia). I am grateful to Mrs. Agáta Pilátová for making the materials of the Society available to me. 
recognised in our Republic and listed in the census forms in the next general census. "8 This request concerned primarily the region at the Slovak - Polish - Ukrainian border in Eastern Slovakia, with a community of approximately forty-thousand, which, in the late 1940s, the Czechoslovak authorities declared to be Ukrainian as a whole. ${ }^{9}$

From the outset the new Society aimed to fulfil two different roles. It became a minority organisation of Ruthenians and, at the same, it united the Czechs which were interested in the region and supported the Ruthenian movement. Most of them, including Jaromír Hořec, the leading figure of the Society were descendants of Czech officials based in in the eastern province during the two inter-war decades. ${ }^{10}$

The general assembly of the Society elected AlexandrVeličko as its Chairman. He was a former officer in the Czechoslovak Army, who became well-known for walking into Soviet Embassy after the 1968 Soviet-led invasion, to return military decorations earned for courage during the Second World War. The nature of the Society as a Ruthenian minority organisation was enhanced by the presence of delegates from the newly founded Ruthenian organisations in Eastern Slovakia and from Transcarpathia. In the following year, the local group was joined by Ruthenian societies in Northern America, Poland, Rumania and Yugoslavia. In March 1991 the first world congress of Ruthenians was in the city of Medzilaborce in Eastern Slovakia. In common declaration, the congress called for "self-determination and dignified life of our nation, densely populating the East-Carpathian region, as well as living in diaspora world-wide." It called upon the governments of the countries with a portion of population identifying as Ruthenians to recognise the sovereignty (svébytnost) of Ruthenia and enable its free development. The congress addressed particularly the Soviet Union and Soviet Ukraine that had not yet recognised the Ruthenians as an independent nation and considered them to be Ukrainians. The declaration envisioned further development of the Ruthenian movement in open-ended way: "The Ruthenian nation, too, wants to pursue its own path and decide independently about its own fate within the family of free nations in the international community." 11

8 Prohlášení Společnosti přátel Podkarpatské Rusi. In: Podkarpatská Rus, 1/[1990?], without date, unpaginated.

9 For the demographic development see the samizdat (illegally self-published) 1980s polemics, HÜBEL, Milan: Češi, Slováci a jejich sousedé. Úvahy, studie a polemiky z let 1979-1989, Prague 1990, 133-135. In the 1991 Census nearly half of this East-Slovak community identified with Ruthenian nationality and this option became even more popular in the future on the expense of the Ukrainian identity. See Kdo žije v ČSFR, in: Rudé právo, 1992, 24 November, 3.

10 As a matter of fact, this strange symbiosis renewed the state of affairs of the 1930s. After years of confused attempts at drafting a nationality policy in Subcarpathia, in the 1930s the Czechoslovak state started to support more systematically the Ruthenian movement, which in the interwar years had been one of the three competing national movements in the region. For the government in Prague, this was a choice of lesser evil. The Great Russian orientation (according to this concept, there were no Ruthenians nor Ukrainians, but only Russians using Russian western dialect) gradually weakened, though due to the support of influential Russophile part of Czech elite and efforts of the Russian exile it remained a viable alternative approximately two decades longer than on the other side of the Carpathian Mountains in the Polish Galicia. In the 1930s the Czech public saw the growing Ukrainian movement as a threat because of its politically dangerous patrons: the Soviet Union and Nazi Germany. Given the choice, the support of Ruthenian autonomy seemed the best option. There was an additional benefit for the Czech society, which in the overwhelming majority had no personal experience with Subcarpathia that it could imagine its own state as a democratic oasis of three peaceful nations without external links, threatened by aggressors from all sides. The activists of the newly established Society took this concept for granted and embarked in their declaration of autumn 1990 upon a mission to return it back to the public life.

11 Prohlášení l. Světového kongresu Rusínů, Medzilaborce, in: Podkarpatská Rus, 1991, 2, 24 March, 3. 
Since the autumn of 1990, the argumentation of the Society was spreading in the Czech public sphere in dozens of articles in the influential nation-wide press. It also started to penetrate political speeches of opposition politicians of various political streams. This was helped by the context of Czech politics that focused on the Czech-Slovak talks about the new shape of the common state and the new treaty with the unified Germany, the themes that explored in detail political, ethnic and legal development in the previous eight decades. The debates were further fuelled by the news about the looming disintegration of the Soviet Union and by Czech public sympathies for the effort in the Baltic states to gain independence. The issue reached the Czech parliament for the first time in November 1990. Member of Parliament Pavel Balcárek from the Movement for Autonomous Democracy Party for Moravia and Silesia (Hnutí za samosprávnou demokracii-Společnost pro Moravu a Slezsko) used the Ruthenian issue as one of the supporting arguments for his demand for transformation of the federation of Czech and Slovak Republics into confederation. He argued that such constitutional arrangement would facilitate unification with Transcarathia in the future: "The proposed confederative arrangement of the Republic ... will be - as I and the others believe - even more pressing in the coming year, should there arise problems for our common state resulting, for instance, from the demands that arose in Eastern Europe, i.e. demands of the people of Subcarpathia for re-unification with our common Republic, from which this country was never separated de iure." 12 The quote demonstrates how quickly the idea spread within the Czech public that, with the disintegration of the Soviet Union, the people of Transcarpathia would call for unification with Czechoslovakia. ${ }^{13}$

In addition to the Moravian autonomists, it was the non-parliamentary Coalition for Republic - Republican Party of Czechoslovakia (Sdružení pro republiku - Republikánská strana Československa) that systematically exploited the issue. Its founder and leader Miroslav Sládek systematically gathered all the demands, which the governments had been unable to respond to and brought them to an extreme. The issue of Transcarpathia appeared in his repertoire early on and became a permanent feature in his agenda. As early as in September 1990 Sládek made the first of his many trips to Transcarpathia and he raised the Czechoslovak flag at the Mukachevo castle. ${ }^{14}$ He took part in the foundation of sister political party in Transcarpathia and submitted an appeal to the International Tribunal in the Hague. The way Miroslav Sládek spoke about the past of Subcarpathia, did not differ at all from the notions of Jaromír Hořec and other activists from his association, except that Sládek harsly criticised the government for its in action in this issue. ${ }^{15}$

12 Česká národní rada [Czech National Council] 1990-1992, the 9 $9^{\text {th }}$ session, 29 November 1990, online: http:// www.psp.cz/eknih.

13 A portion of Moravian and Bohemian public dreamed about a federal state composed of federal lands of Bohemia, Moravia and Slovakia - ideally also with Subcarpathian Russia. The concept proved utterly unacceptable to Slovakia as it would thus have degraded it from at least formal co-ruler within the federation into a region of lesser significance.

14 See study of Petr Roubal in: GJURIČOVÁ, Adéla - KOPEČEK, Michal - ROUBAL, Petr - SUK, Jiří ZAHRADNÍČEK, Tomáš: Rozděleni minulostí. Vytváření politických identit v České republice po roce 1989, Prague 2011, 338.

15 SLÁDEK, Miroslav: Návrat do Evropy. Podkarpatská Rus, in: Republika, 4 February 1991: "The relation of the Ruthenians to the neighbouring nations is given by the bitter experience of the national oppression, which now culminates in the effort to remake the Ruthenians into Ukrainians and wipe out their language as well. The local 


\section{After the Moscow Coup}

The Ruthenian issue reached the main stream of Czech politics in the summer and autumn of 1991 in connection with the Moscow Coup and the subsequent process of Ukrainian break up from the Soviet Union. The split of the ruling Civic Forum (Občanské fórum) into two parties - the Civic Movement (Občanské hnutí, CM) and Civic Democratic Party (Občanská demokratická strana, CDP), and their mutual rivalry also played an important role. The Minister of Foreign Affairs Jiři Dienstbier, the leader of the Civic Movement, came increasingly under pressure from the Civic Democratic Party of Václav Klaus, which was joined by majority of the former Civic Forum members of the Federal Assembly. Jaroslav Suchánek, MP from CDP gave a speech in the heated debate at Foreign Committee of the Federal Assembly that was held immediately after the return of Mikhail Gorbachev from house arrest. Suchánek presented a list of nine demands outlining how Czechoslovakia should respond to the new situation. The third demand suggested that Czechoslovakia should express its commitment that "regardless of which state Transcarpathian Russia (sic) decides to join, our doors are open to it." 16

The most extensive debate on the issue in the Federal Assembly took place on 5 December 1991 during the discussion about foreign policy report presented by the Minister of Foreign Affairs. The belief in of utter success of the Ukrainian independence referendum was so strong, that the issue of Transcarpathia became the second most often mentioned concrete issue concerning Czechoslovak foreign policy, right after the Czechoslovak German Treaty. The urgency of the matter was further stressed by a short article published the same day, in which a representative of the Society of Carpathian Ruthenians from Uzhgorod estimated that "if a referendum in Transcarpathia about joining Czechoslovakia was to take place, $60 \%$ of the people would vote in support." 17 Two influential deputies, Josef Lux, the Chairman of the Christian and Democratic Union - Czechoslovak People's Party (Křestáansko demokratická strana - Československá strana lidová) and Karol Stomme from Civic Democratic Party, tabled parliamentary resolution binding the government to act on the issue of Transcarpathia before it recognised the independent Ukraine. ${ }^{18}$ The Parliament did not adopt these proposals, but the discussion caused that, for several next weeks, Transcarpathia was the focus of Czech political debates. it was discussed twice in the most popular televised political debates, the pressure on the government was stepped up by the press and declarations by various associations, such as the veteran Union of Freedom Fighters or the former government in exile, The Council of Free Czechoslovakia.

inhabitants, however, have exceptional relationship to Czechs. The older generation remembers the period of the First Republic as the time of the greatest development of Subcarpathia. ... The entire Europe is in turmoil. It is therefore even more striking fact, that the parliament, government and even president of Czechoslovak Republic is not concerned with the fate of Subcarpathia."

16 Klaus požaduje čistky, in: Rudé právo, 1991, 24 August, 1. At the time the Civic Democratic Party didn't yet have its own set foreign policy concept and the MPs who identified with the party, were free to subject it to criticism, something that was not binding for the future. After the disintegration of Czechoslovakia Mr Suchánek, MP was appointed the Czech Ambassador in Australia.

17 Postoj Ukrajiny ke svazové smlouvě, in: Rudé právo, 1991, 5 December, 15.

18 Federální shromáždění České a Slovenské Federativní Republiky [Federal Assembly of The Czech and Slovak Federative Republic] 1990-1992, the 19th session, 5 December 1991, online: http://www.psp.cz/eknih. 
Foreign Minister Dienstbier and his supporters defended their positions. The official reply stated that borders in Europe couldn't be changed. It was only possible to limit their significance and negotiate different forms of cross-border cooperation. In his later memoirs, Dienstbier recalled that he had considered the entire issue to be de facto a part of the Czech debate about the past that concerned far more Prague and Czech sentiments than Transcarpathia and the will of its peoples. He commented on his reservations: "I wanted to point that that, so far the attachment was only supported by an active group in Prague that presented the issue on daily basis. "19 The government spokesmen and the friendly press called these calls amateurish, unrealistic and irresponsible and manage to maintain their line till the election in June 1992.

The election meant a disaster for Dienstbier's Civic Movement: despite the hundred of ministers and deputies, sympathies among the media and the support by President Václav Havel it did not manage to cross the five percent threshold to enter the parliament. ${ }^{20}$ The election winners were Civic Democratic Party in the Czech Lands and Movement for a Democratic Slovakia (Hnutí za demokratické Slovensko) led by Vladimír Mečiar in Slovakia, which meant that the destiny of Czechoslovakia was doomed. At the same time, there was a shift in the CDP foreign policy agenda. The former spokesperson resigned and the new policy, represented by the future long-term Czech Foreign Minister Josef Zieleniec, was presented. The policy that was in line with majority public opinion, understood the split with Slovakia as a permanent retreat of Czech political interests from the East.

The political change coincided with a shift in the Czech media. Responding to the debate, all key press sent, for the first time, in the summer of 1992 their reporters to Transcarpathia to cover its state after nearly half a century of Soviet rule. The result, if we can sum up the general tone of some twenty reports in the main Czech newspapers and journals, must have greatly disappointed enthusiastic supporters of the re-engagement in the East. "When we came to Subcarpathia, our goal was clear. We wanted to find those who speak Czech, find out how many of them they are and how they remember Czechoslovakia," a journalist of the daily Prostor described the typical motivation of the Czech press. ${ }^{21}$ Yet the series of his reports, published in June 1992 eventually spoke about something altogether different. They were about the troubles at the border, misuse of power by the officials, alcoholism, poverty, chaos and ethnic indifference of majority of citizens. Czech journalists were seeking strong Ruthenian national awakening and generally shared nostalgia for the interwar Czechoslovakia, to have to honestly admit that they found none of that. Every one of them met an old man, who learned Czech at school or in the army and said a few nice words about his youth and former Czechoslovakia or sang Czech anthem, but that was all. The journalists did not find any significant traces of Ruthenian national movement that would confirm the claims of local intellectuals that the country had been Ukrainised only superficially. Czech readers had to accept that any idea of re-unification was unrealistic and that it was merely backed in Transcarpathia by a handful of writers and intellectuals without any wider appeal to local public. Through the summer and autumn of 1992 the

19 DIENSTBIER, Jiří: Od snění k realitě. Vzpomínky z let 1989-1999, Praha 1999, 281.

20 According to the internal documents of the Society of Friends of Subcarpathia, Jiři Dienstbier approached the Society several months after his election defeat and proposed a cooperation with its non-parliamentary party.

21 VOJTíŠEK, Stanislav: Jasinské elegie aneb Strach má dlouhé nohy, in: Prostor, 1992, 17 June, 12. 
Transcarpathian issue disappeared from Czech politics as quickly as it appeared in 1990. The Czechs were partly frustrated that they could not kept Slovakia. Yet, at the same time, they were pleased that the split was proceeding swiftly and without any major difficulties, what contrasted with the breakup of the other East European multinational states.

Finally, let 's look at further development of the questions that this issue opened up in Czech public after 1989. The Ruthenian movement in Transcarpathia failed. In the 2001 census (the first where local population could identify its ethnicity) only ten thousand out of 1.5 million citizens identified as Ruthenians of the region; the overwhelming majority opted for Ukrainian ethnicity. On the Slovak border, a reversed process took place and majority of the local minority considered themselves Ruthenians, not Ukrainians. So far, there has not been any interest in research into the region and its history during the interwar Czechoslovakia. A translation from Slovak of the monograph by Prešov-based historian Peter Švorc published in 2007 is the first study in Czech to critically explore the Czech administration, document the actual difficulties and note the frustration of the contemporary residents in the region, is. ${ }^{22}$

The theme virtually disappeared from political life. Except that the Coalition for Republic Republican Party of Czechoslovakia led by Miroslav Sládek maintained the unification with Transcarpathia in their agenda. ${ }^{23}$ Referring to the example of the United States and Alaska, the it argued that there didn't have to be physical proximity with the former province for the two to be united. The positive attitude on the part of the Czech public to Transcarpathia did not disappear: it is manifested every summer, when Transcarpathia becomes highly popular Czech tourist destination. Such sentimental tourism represents a substantial part of local economy in some remote mountain villages, made famous by Czech interwar writers. Within the context of the current revival of ethno-religious sentiments in Central and Eastern Europe, largely fuelled by Russian geopolitical revisionism, sentimental historic memory is but one of many manifestations of these developments that that deserve further study.

\section{References}

Česká národní rada [Czech National Council] 1990-1992, the $9^{\text {th }}$ session, 29 November 1990.

DUCHÁČEK, Ivo: Jak Rudá armáda mapovala střední Evropu: Těšínsko a Podkarpatsko, in: Svědectví, 1981, 63, 541-581.

Federální shromáždění České a Slovenské Federativní Republiky [Federal Assembly of the Czech and Slovak Federative Republic] 1990-1992, the 19th session, 5 December 1991. HOŘEC, Jaromír: Nedělitelná svoboda, in: Tvorba, 1990, 15, 11.

Klaus požaduje čistky, in: Rudé právo, 1991, 24 August, 1.

Kdo žije v ČSFR, in: Rudé právo, 1992, 24 November, 3.

PILÁTOVÁ, Agáta: in: Tvorba, 1990, 20, 18.

Podkarpatská Rus, č. 1/[1990?].

Postoj Ukrajiny ke svazové smlouvě, in: Rudé právo, 1991, 5 December, 15.

22 ŠVORC, Peter: Zakletá zem: Podkarpatská Rus 1918-1946, Prague 2007. The book first appeared in Slovakia in 1997.

23 The party was in the Czech parliament between 1992 and 1998. 
Prohlášení I. Světového kongresu Rusínů, Medzilaborce, in: Podkarpatská Rus, 1991, 2, 24 March, 3.

SKOTARSKÝ, Jan: Podkarpatské otazníky, in: Reportér, 1990, Vol. 5, No. 13, 18-22.

SLÁDEK, Miroslav: Návrat do Evropy. Podkarpatská Rus, in: Republika, 4 February 1991.

VOJTÍŠEK, Stanislav: Jasinské elegie aneb Strach má dlouhé nohy, in: Prostor, 1992, 17 June, 12.

DIENSTBIER, Jiří: Od snění k realitě. Vzpomínky z let 1989-1999, Praha 1999.

GJURIČOVÁ, Adéla - KOPEČEK, Michal - ROUBAL, Petr - SUK, Jiří -ZAHRADNÍČEK, Tomáš: Rozděleni minulostí. Vytváření politických identit v České republice po roce 1989, Prague 2011.

HOŘEC, Jaromír: Nedělitelná svoboda. Podkarpatská Rus, Prague 1992.

HÜBEL, Milan: Češi, Slováci a jejich sousedé. Úvahy, studie a polemiky z let 1979-1989, Prague 1990.

RAŠKA, Francis D.: Fighting Communism from Afar: The Council of Free Czechoslovakia, Boulder 2008.

ŠVORC, Peter: Zakletá zem: Podkarpatská Rus 1918-1946, Prague 2007.

\section{Author}

Mgr. Tomáš Zahradníček, Ph.D.

Ústav pro soudobé dějiny AV ČR, v.v.i.

Institute of Contemporary History, The Czech Academy of Sciences

Puškinovo nám. 9, 16000 Praha 6, The Czech Republic

tzahradnicek@seznam.cz 